\title{
GM-CSF-secreting Lethally Irradiated Tumor Cell Vaccine
}

National Cancer Institute

\section{Source}

National Cancer Institute. GM-CSF-secreting Lethally Irradiated Tumor Cell Vaccine. NCI

Thesaurus. Code C1978.

An autologous or allogeneic cell vaccine comprised of tumor cells which have been lethally irradiated and genetically modified to secrete granulocyte-macrophage colony stimulating factor (GM-CSF), a hormone which plays a key role in stimulating the body's immune response to vaccines. GM-CSF may stimulate the body's immune system against tumor cells by attracting and enhancing the activation of antigen-presenting cells (APCs), such as dendritic cells (DCs). This promotes antigen presentation to Tlymphocytes and induces a cytotoxic $T$-lymphocyte $(C T L)$ response against cells expressing tumor-associated antigens (TAAs). 